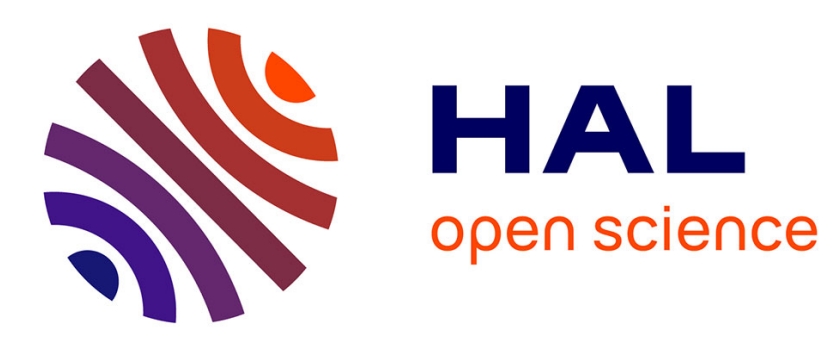

\title{
Occurence and removal of priority pollutants by lamella clarification and biofiltration
}

Johnny Gasperi, Vincent Rocher, Solène Gilbert, Sam Azimi

\section{To cite this version:}

Johnny Gasperi, Vincent Rocher, Solène Gilbert, Sam Azimi. Occurence and removal of priority pollutants by lamella clarification and biofiltration. Water Research, 2010, 44 (10), pp.3065-3076. 10.1016/j.watres.2010.02.035 . hal-00657079

\section{HAL Id: hal-00657079 \\ https: / hal-enpc.archives-ouvertes.fr/hal-00657079}

Submitted on 5 Jan 2012

HAL is a multi-disciplinary open access archive for the deposit and dissemination of scientific research documents, whether they are published or not. The documents may come from teaching and research institutions in France or abroad, or from public or private research centers.
L'archive ouverte pluridisciplinaire HAL, est destinée au dépôt et à la diffusion de documents scientifiques de niveau recherche, publiés ou non, émanant des établissements d'enseignement et de recherche français ou étrangers, des laboratoires publics ou privés. 


\title{
OCCURRENCE AND REMOVAL OF PRIORITY POLLUTANTS BY LAMELLA CLARIFICATION AND BIOFILTRATION
}

\author{
Johnny Gasperi ${ }^{1 *}$, Vincent Rocher ${ }^{2}$, Solène Gilbert ${ }^{1}$ and Sam Azimi ${ }^{3}$
}

1. Université Paris-Est, LEESU, UMR MA 102 - AgroParisTech, 61 avenue du Gal de Gaulle, 94010 Créteil Cedex, France

2. SIAAP, Direction du Développement et de la Prospective, 82 avenue Kléber, 92700 Colombes, France

3. SIAAP - Site Seine Centre, 7-8 boulevard Louis Seguin, 92700 Colombes, France

\section{Abstract}

This study investigates the occurrence of all priority substances $(n=41)$ listed in the Water Framework Directive and additional substances $(n=47)$ in raw sewage, as well as the removal performance of lamella clarification and biofiltration techniques. Once the efficiency of both types of techniques has been assessed for typical wastewater parameters, the differences in each technique's ability to remove pollutants becomes obvious; nevertheless, pollutant removal in quantitative terms still depends on the physico-chemical properties of the compounds used and operating conditions within the selected facility. For lamella clarification, the removal of organic chemicals was found to be primarily correlated with their sorption potential and, hence, strongly dependent upon $\log \mathrm{K}_{\mathrm{ow}}$ of the compound under study. Compounds with a strong hydrophobic character ( $\log \mathrm{K}_{\mathrm{ow}}>4.5$ ) are removed to a significant extent (approx. 85\%), while hydrophilic compounds ( $\left.\log \mathrm{K}_{\text {ow }}<3.5\right)$ are poorly removed (< 20\%). For biofiltration, the removal of chemicals appears to be compound-dependent, although this outcome involves several mechanisms, namely: i) physical filtration of total suspended solids, ii) volatilisation, iii) adsorption on biomass, and iv) biotransformation of substances. Even if the complex processes within a biofilter system do not yield an accurate prediction of pollutant removal, two groups of chemicals can still be clearly identified: i) hydrophobic or volatile compounds, for which moderate to high removal rates are observed (from $50 \%$ to over $80 \%$ ); and ii) hydrophilic, non-volatile and refractory compounds for which a low removal rate would be expected $(<20 \%)$.

\section{Keywords}

Lamella clarifier, biofiltration, priority pollutants, Water Framework Directive

\footnotetext{
* Corresponding author: Fax: +33 (0)1 451716 27, e-mail: gasperi@univ-paris12.fr
} 


\section{1. Introduction}

The European Community's strategy to combat surface water pollution by means of adopting a control policy was set forth in the European Water Framework Directive 2000/60/EC (WFD, Decision No. 2455/2001/EC). This directive offered the first list of 33 substances or groups of substances to be identified as action priorities at the Community level and required EU Member States to ensure a "satisfactory chemical and biological status for surface waters" by 2015. This proposal has therefore mandated a gradual reduction in emissions, losses and discharges of all priority substances, along with a phase-out or cessation of emissions, losses and discharges of priority hazardous substances over a 20-year period.

In pursuit of the WFD objectives, several steps have been taken to considerably reduce stormwater pollution (storage tanks, stormwater treatment facilities, etc.) and improve the efficiency of wastewater treatment technologies. On the one hand, these improvements have led to a significant decrease of carbonaceous and nutriment pollution in receiving waters, while on the other these improvements have played an important role in minimising the release of xenobiotics into the aquatic environment. Regarding this point, among the various wastewater technologies available, conventional activated sludge wastewater treatment plants (AS-WWTPs) are the most well-documented. Numerous studies have already been conducted on the fate of certain priority substances or emerging pollutants in AS-WWTPs (Fauser et al., 2003; Jacobsen et al., 2004; Katsoyiannis and Samara, 2004; Vogelsang et al., 2006; Clara et al., 2005). Despite the contribution of this experimental work, data are currently lacking on the removal of WFD priority pollutants using more compact wastewater treatment technologies, which have now become widely implemented in modern WWTPs. Among such technologies, lamella clarification and biofiltration (aerated or non-aerated biological filters) are particularly attractive. 

clarifier. A coagulant (causing destabilisation of colloidal particles) and polymer (promoting floc formation) are then injected into the influent wastewater prior to entering the flocculation zone. Since this technique is operated more compactly and contains less exposed surface area,

5 lamella clarification is considered an essential process in wastewater treatment and is widely applied to provide advanced primary treatment, in addition to producing a highly-clarified effluent (Tchobanoglous et al., 2003). This type of method can also serve to treat wet weather flows or combined sewer overflows.

The biofiltration technique has been derived from drinking water production filters and combines physical and biological purification processes using an immersed filtration material (aerated or not, depending on the desired treatment), onto which the bacteria populations ready for pollution abatement will settle. The benefits of these immersed biological systems lie in their compactness (small site encumbrance), modularity (treatment procedure can be adapted to match the wastewater flow the plant is able to accommodate) and intensiveness (short hydraulic retention time). As a result of these advantages, biofilters have become an alternative to activated sludge tanks and are perfectly suited for treatment plants built in large urban areas, where real estate development pressures make available land scarce.

Though both types of techniques are implemented in modern WWTPs and despite them being highly recommended and increasingly popular for stormwater management, only limited data are presently available on the removal of all WFD priority substances through application of such techniques. Most studies in the literature focus on a group of substances or on performance in removing carbonaceous and nutriment pollutants (Mendoza-Espinosa and Stephenson, 1999; Chang et al., 2004; Imasuen et al., 2004; Rocher et al., 2006 and 2008). 
This study was therefore launched as part of the OPUR (Observatory of Urban

2 Pollutants in Paris) research programme, with the objective of examining the removal of all priority pollutants and additional compounds by means of lamella clarification and biofiltration. For this purpose, the Seine Centre WWTP, which is localized in the Parisian suburban and combines both technologies, was selected during a total of three sampling campaigns. A total of 88 substances (ranked into 13 groups of compounds) were determined in raw sewage as well as at particular points within the WWTP. The distribution of pollutants between the dissolved and sorbed phases of wastewater was also investigated.

\section{Materials and methods}

\subsection{Wastewater treatment plant description}

The Seine Centre plant receives some $240,000 \mathrm{~m}^{3} \cdot \mathrm{d}^{-1}$ of wastewater. The treatment process comprises: screening, grit removal, primary sedimentation using coagulant and flocculant, followed by biofiltration units (Fig. 1). Raw sewage is initially pre-treated; this stage includes screening and grit/oil removal, thus allowing the removal of coarse floating solids, sand and some grease components. Following this pre-treatment, the wastewater undergoes physical and chemical treatment, which traps a large amount of particles and phosphorus. This step is performed by lamellar settling (use of 9 settling tanks - Densadeg®), with the addition of both a coagulant (ferric chloride) and flocculant (anionic polymer).

After primary treatment, a biological treatment takes place over 3 stages of biofilters. The first stage (24 Biofor ${ }^{\circledR}$-type filters with biolite as the medium) is aerated and mainly serves to remove carbonaceous pollution. The second stage (29 Biostyr ${ }^{\circledR}$-type filters with biostyrene as the medium) is also aerated and allows for the nitrification of ammoniacal pollution. Lastly, the denitrification step occurs during stage 3 (12 Biofor®-type filters), which is not aerated. Denitrification requires adding methanol, which acts as an exogenous 
1 carbonaceous substrate. Once this biological treatment has been completed, effluents are

2 discharged into the Seine River.

\subsection{Experimental procedure}

During this study, 3 sampling points, corresponding to raw sewage (RS), decanted effluents (DE) and final effluents (FE), were considered (Fig. 1). In 2008, three sampling campaigns were carried out (March, September and December). At each site, 24-h composite samples were collected using automatic refrigerated samplers (at $4^{\circ} \mathrm{C}$ ). To avoid problems associated with sample contamination and/or pollutant adsorption during sampling, the samplers were equipped with glass bottles and Teflon ${ }^{\circledR}$ pipes. In accordance with the constraint to analyse 88 substances on the particulate material (i.e. from 0.2 to $2.0 \mathrm{~g}$ of particles were required), large volumes had to be collected (10 l for RS, $30 \mathrm{l}$ for DE and FE), and the sampling campaigns had to be performed on three consecutive days. Each day, 3 or 4 groups of compounds were analysed. To avoid any modification of pollutant distribution between the dissolved and particulate phases, samples were filtered as soon as possible on a 0.45 - $\mu m$ filter. After filtration, the dissolved phase was quickly sent to the laboratory for analysis. As for the particulate material, filters were first lyophilised and then sent to the laboratory.

Based on the WFD list, 41 individual substances were initially considered. Depending on the chemical group, 1 to 13 additional substances were also included (Table 1), thereby accounting for 88 compounds. Except for the metals, halogenated volatile organic compounds (HVOCs) and BTEX (benzene, toluene, ethylbenzene and xylenes), which were analysed on the total fraction, the dissolved and particulate fractions were assessed for each individual compound. Analysis work was performed at the IPL-Bretagne laboratory, certified by France's Environment Ministry (via the COFRAC accreditation committee). 
$1 \quad$ 3. Results and discussion

\subsection{Priority pollutants in raw sewage}

Of the 88 molecules targeted, 51 (including 18 substances listed in the WFD) were detected in RS. All non-detected compounds along with their limits of detection (LOD) have been listed in the Supplementary Material section (Table 1). Among the pollutants detected, 12 substances (7 pesticides, mono- and di-butyl tin, polychlorobiphenyls 183 and 153, and ethylbenzene) were highlighted since they could all be detected once during the three campaigns performed, with concentrations for these elements lying at or close to the LOD.

In all, 39 substances were thus selected to study chemical removal using the lamella clarification method. Total concentrations, as well as their respective LOD, are reported in Fig. 2. The array of molecules detected and corresponding concentration ranges are typically representative of data found in the literature on wastewater (Gasperi et al., 2008a in France, or Rule et al., 2006a and b in the United Kingdom). As regards contaminant levels, three groups of chemicals can be distinguished.

The first group includes metals and di(2-ethylhexyl) phthalate (DEHP); it displays the highest concentrations (10-300 $\left.\mu \mathrm{g} \cdot \mathrm{l}^{-1}\right)$. Metal concentrations lie between 180 and $260 \mu \mathrm{g} . \mathrm{l}^{-1}$ for $\mathrm{Zn}$, between 70 and $90 \mu \mathrm{g} . \mathrm{l}^{-1}$ for $\mathrm{Cu}$, and 13-15 $\mu \mathrm{g} . \mathrm{l}^{-1}$ for $\mathrm{Pb}$. Like for DEHP, the concentration is bound within the 10-25 $\mu \mathrm{g} \cdot \mathrm{l}^{-1}$ range. The presence of these substances stems from their extensive use both throughout industry and in household products. Metals are currently used as chemical additives in a wide variety of consumer products or input into a number of metal finishing processes (Rule et al., 2006a and b). Similarly, DEHP is widely used as an additive in plastics (Wams, 1987).

The second group (6 volatile compounds, nonylphenol - NP, and amino methyl phosphonic acid - AMPA) contains total concentrations in the 1.0-6.0 $\mu g . l^{-1}$ range. Due to their excellent degreasing properties, the HVOCs and BTEX presence can certainly be related 
1 to their widespread use as a degreasing agent and solvent. For example, tetrachloroethylene is introduced primarily for dry cleaning and metal degreasing purposes yet can also be found in numerous household products (CEPA, 1993). The presence of NP (1.0-1.7 $\left.\mu g . \mathrm{l}^{-1}\right)$ results mainly from the degradation of alkylphenol polyethoxylates, which are extensively used as non-ionic surfactants in many industrial, commercial and laboratory detergents and industrial processes (Ying et al., 2002); this presence might also be correlated with the direct application of alkylphenols as plasticisers in plastics. Lastly, AMPA has been observed in RS 
Since this section only discusses total concentration values, more detailed information on the partitioning of chemicals is available in the Supplementary Material section (Table 2).

\subsection{Pollutant removal during wastewater treatment}

This study is aimed at examining the removal of priority pollutants by means of clarification and biofiltration. Prior to assessing pollutant removal levels, some precise knowledge is required for removing conventional pollutants. Consequently, the efficiency of both techniques was examined as an initial step for typical wastewater parameters, such as total suspended solids (TSS), chemical and biochemical oxygen demand (COD and BOD), ammonium $\left(\mathrm{NH}_{4}^{+}\right)$, total Kjeldahl nitrogen (TKN), total phosphorus $\left(\mathrm{P}_{\text {tot }}\right)$ and orthophosphates $\left(\mathrm{PO}_{4}{ }^{3-}\right)$. Data obtained in 2008 at the Seine Centre plant were processed; all analyses were conducted on 24-h composite samples at similar points in the plant.

\subsubsection{Lamella clarifier}

\section{Conventional wastewater parameters}

The removal rates (in \%) of conventional wastewater parameters (TSS, total and dissolved COD - CODtot and CODs, BOD, TKN, $\mathrm{P}_{\text {tot }}$ ) with clarification are illustrated in Fig. 3 (the box plot illustration indicates the median, d25 and d75 percentile removal rates). In addition, median concentrations \pm standard deviations (SD) are shown for RS and DE.

First of all, Fig. 3 displays the high efficiency of lamella clarifier for TSS and total COD pollution. For these elements, median removal rates were evaluated at $86 \%$ for TSS and

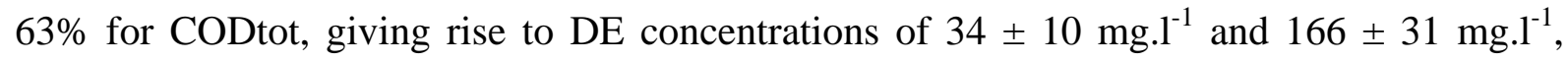
respectively. No seasonal variations or temperature influence was remarked, and the decanted effluent concentrations appeared not to be influenced by the quality of raw sewage entering the facility. This trend has resulted primarily from adapting clarification operating conditions in accordance with the quality of influent, by adjusting the ferric chloride (25 and 40 g.m $\mathrm{m}^{-3}$ ) 
1 and polymer doses (0.3 and 0.45 g.m $\mathrm{m}^{-3}$ ). BOD was also removed to a great extent by clarification (63\% removal rate, with a concentration in DE at $69 \pm 15$ mg. ${ }^{-1}$ ). This high removal rate is correlated with the elimination of particles and colloids. The dissolved organic pollution removal is rather slight, yet nevertheless able to reach a $20 \%$ median (Fig. 3).

For nitrogen, only a small portion is removed by clarification (40 mg N.l ${ }^{-1}$ in RS vs. 35 mg N. $\mathrm{l}^{-1}$ in DE). This limited elimination rate is related to the removal of organic nitrogen (mainly associated with particles), whereas $\mathrm{NH}_{4}{ }^{+}$is predominant in wastewater (approx. 80\% of total nitrogen) and principally in dissolved form (Boari et al., 1997).

Furthermore, phosphorus pollution removal is considerable, as demonstrated by the removal rates for $\mathrm{PO}_{4}{ }^{3-}$ and $\mathrm{P}_{\text {tot }}$ (81\% and $75 \%$, respectively). DE concentrations equal

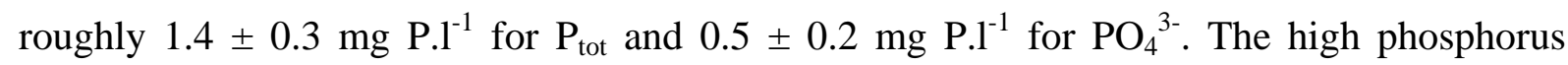
pollution elimination rate is tied to particle sedimentation and, to a greater extent, to $\mathrm{PO}_{4}{ }^{3-}$ precipitation with the ferric ion $\left(\mathrm{FePO}_{4}\right)$.

During the three sampling campaigns, median influent flow was about $240,000 \mathrm{~m}^{3} \cdot \mathrm{d}^{-1}$. The removal rates for conventional wastewater parameters with lamella separator were close to those obtained using conventional and typical operating modes (87\% $\pm 2 \%$ for TSS, $63 \% \pm$ $4 \%$ for CODtot, $64 \% \pm 3 \%$ for BOD, $75 \% \pm 6 \%$ for $\mathrm{P}_{\text {tot }}$, and $81 \% \pm 10 \%$ for $\mathrm{PO}_{4}{ }^{3-}$ ).

\section{Priority substances}

Table 2 summarises, for all molecules detected, the observed removal rates with lamella separator. According to these results, the pollutants studied can be classified as: i) "poorly removed" compounds, when the elimination rate is below 20\%; ii) "weakly removed" compounds, when this rate ranges between $20 \%$ and 50\%; iii) "moderately removed", with an elimination rate of $50 \%$ to $80 \%$; and lastly iv) "efficiently removed", i.e. a rate above $80 \%$. 
-Experimental results

According to the previously defined criteria, metals are moderately removed by clarification (> 33\% for $\mathrm{Pb}$ and between $50 \%$ and $80 \%$ for $\mathrm{Zn}$ and $\mathrm{Cu}$ ). Total metal concentrations decreased markedly between RW and DE, thus confirming the strong impact of lamella clarifier and suggesting that the removal of metals is likely to be strongly correlated with the affinity of these metals for particles (Buzier et al., 2006). As reported by Gasperi et al. (2008b) for Paris wastewater, 40\%-80\% of $\mathrm{Zn}$ and $75 \%-95 \%$ of $\mathrm{Pb}$ and $\mathrm{Cu}$ are associated with particles.

Depending on the physico-chemical properties of the pollutant, removal rates for organic pollutants vary significantly. HVOCs and BTEX are only weakly removed by clarification (<20\%), while heavy molecular weight PAHs (4-6 rings, HMW PAHs) are efficiently removed ( $>$ 80\%). The differences observed are in fact tied to the hydrophobicity of the compounds, which may be reflected by the octanol - water coefficient $\left(\mathrm{K}_{\mathrm{ow}}\right)$. As suggested by Rogers (1996) and Byrns (2001), hydrophobic compounds (log $K_{o w}>4$ ) are associated mainly with particles and hence efficiently removed by means of decantation. On the other hand, hydrophilic compounds ( $\log \mathrm{K}_{\mathrm{ow}}<4$ ) are weakly removed since they preferentially occur during the dissolved phase. This trend is clearly highlighted in Fig. 4. For hydrophilic compounds (log $\mathrm{K}_{\mathrm{ow}}<4$ ), removal rates vary considerably yet still lie below 20\%. In this study, 18 substances with a strong hydrophilic character are involved (6 pesticides, 6 HVOCs and BTEX, 3 light molecular weight PAHs (LMW PAHs), and 3 individual substances). For hydrophobic compounds ( $\log K_{o w}>4$ ), three groups are distinguishable: i) Group $1\left(4.0<\log \mathrm{K}_{\mathrm{ow}}<4.5\right)$, with removal rates between 20\% and 50\%; Group $2\left(4.9<\log \mathrm{K}_{\mathrm{ow}}<7.2\right)$, with removal rates of $50 \%$ to $80 \%$; and iii) Group $3(5.6<\log$ $\left.\mathrm{K}_{\mathrm{ow}}<6.7\right)$, with removal rates exceeding $80 \%$. 


\section{-Theoretical approach}

Three main mechanisms require special attention in order to predict the removal rates of pollutants during wastewater treatment, i.e.: i) sorption, ii) volatilisation, and iii) biodegradation (Byrns, 2001). For high-rate clarification, it can reasonably be assumed that sorption prevails while both volatilisation (no stripping) and biodegradation (short hydraulic retention time and no high biomass concentration) processes exert only a minor influence. The removal of chemicals as part of the clarification technique is therefore predominantly linked to their sorption potential on primary settled sludge. According to Karickhoff (1984), the adsorption of hydrophobic non-polar organic compounds is commonly described as a linear function of both the $\mathrm{K}_{\mathrm{ow}}$ of the solute and the organic carbon content of the adsorbent

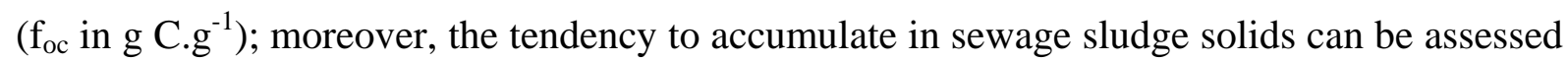
using both parameters. The phase partitioning of a given pollutant between dissolved and sorbed phases can thus be computed using the eq. 1 adapted from Byrns (2001).

$$
\begin{aligned}
& F D W=100 \times \frac{1}{\left(1+6.3 \times 10^{7} \times F_{O C} \times K_{O W} \times[T S S]_{R S}\right)} \\
& F S S=100-F D W
\end{aligned}
$$

Eq 1 adapted from Byrns (2001)

$$
\begin{array}{ll}
\text { with: } & F D W=\text { Fraction of chemical dissolved in water } \\
& F S S=\text { Fraction of chemical sorbed on solids } \\
F_{O C}=0.7 \mathrm{~g} \mathrm{C.} \mathrm{g}^{-1} \text { (Tchobanoglous et al., 2003) } \\
{[T S S]_{R S}=\text { Total suspended solid concentration in raw sewage }}
\end{array}
$$

The fraction of chemical dissolved in water (FDW) is shown in Fig. 5 as a function of $\log \mathrm{K}_{\text {ow }}$ (black squares). Experimental partitioning, when available, is also indicated on this figure (white squares). Once the fraction of pollutant sorbed on the solid (FSS) had been evaluated, the theoretical removal was calculated according to the TSS removal rate. Fig. 5 then compares experimental (median value $\pm \mathrm{SD}$ ) with theoretical removal rates.

For compounds offering the possibility of comparison, a good correlation between prediction, experimental FDW and removal rates can be observed. Below a log $\mathrm{K}_{\mathrm{ow}}$ of around 2, FDW is predominant and, consequently, the compounds are weakly removed $(<20 \%)$. In 
1 contrast, the compounds with a $\log \mathrm{K}_{\mathrm{ow}}$ of above 5 are preferentially associated with particles and hence efficiently removed $(80 \% \pm 10 \%)$, except for DEHP which displays a slightly lower removal rate (70\% vs. 86\%). For compounds with a $\log K_{\text {ow }}$ between 4 and 5, FDW ranges from $12 \%$ to $51 \%$, meaning that removal rates can vary significantly (20\%-80\%).

The good correlation between experimental and theoretical results justifies the empirical predictive approach for easily determining the evolution of pollutants during primary treatment. The above procedure provides a suitable description of sorption behaviour and therefore furnishes important information on the evolution of a wide array of non-polar organic compounds during lamella clarification. Theoretical approaches are critical to wastewater management since the set-up and execution of experimental campaigns is complex and expensive. Model generalities for screening purposes can be extended to polar organics and trace metals through the use of alternative formulations to describe the relevant partitioning phenomena. Although a number of empirical methods can be implemented to predict the extent of partitioning, the Kd (distribution coefficient) for polar or charged compounds in aquatic systems can be evaluated using laboratory tests, as performed by Ternes et al. (2004) for pharmaceuticals and musk fragrances.

\subsubsection{Biofiltration}

\section{Conventional wastewater parameters}

The removal rates for typical wastewater parameters with biofiltration are displayed in Fig. 6; in addition, median concentrations \pm SD have been indicated for DE and FE.

Results reveal that a significant portion of TSS are treated when settled effluents flow through the biofiltration units $(89 \% \pm 5 \%)$. TSS concentrations in the final effluents were typically found in the 3-7 mg. $\mathrm{l}^{-1}$ range. According to Rocher et al. (2006), the first stage 
1 performs the physical filtration of particles, while the subsequent biofiltration units play a minor role in particle filtration.

By combining the physical and biological purification processes, biofiltration can effectively treat carbonaceous, nitrogenous and phosphorous pollution. For carbonaceous pollution, the 3-stage biofilter system removes over $92 \%$ and $83 \%$ of BOD and COD loads, respectively. Like for TSS, BOD is mainly consumed during the first stage (Rocher et al., 2006): concentrations do not exceed $10 \mathrm{mg} \mathrm{O}_{2} \cdot \mathrm{l}^{-1}$ (with the median being $5.9 \mathrm{mg} \mathrm{O} \mathrm{O}_{2} \cdot \mathrm{l}^{-1}$ ). In spite of the significant removal of COD loads, a residual organic pollution, mainly in dissolved form, is commonly observed in discharged effluents at a level of about $30 \mathrm{mg} \mathrm{O}_{2} \cdot \mathrm{l}^{-1}$. For the nitrogenous pollution, removal rates of roughly $99 \%$ are observed for $\mathrm{NH}_{4}^{+}$(FE concentrations at $0.4 \mathrm{mg} \mathrm{N} . \mathrm{l}^{-1}$ ). Water transit through the biofiltration units is accompanied by the biological oxidation of ammonia-containing pollutants. The nitrification process intensifies during the second stage, when over $95 \%$ of ammoniacal pollution is oxidised $(0.7$ $\mathrm{kg} \mathrm{NO}_{3}{ }^{-} / \mathrm{m}^{3}$ media.d $\mathrm{d}^{-1}$, with an aeration of approx. $100 \mathrm{Nm}^{3}$ /applied $\mathrm{kg}$ of $\mathrm{NH}_{4}{ }^{+}$). Within the stage 3, nitric nitrogen formed upon the oxidation of ammonia-containing pollutants is reduced to atmospheric nitrogen. The efficiency of nitrification and denitrification stages minimizes the discharges of nitrogen inputs $\left(\mathrm{NH}_{4}{ }^{+} / \mathrm{NO}_{3}{ }^{-}\right)$in aquatic systems. Moreover, biofiltration allows for the efficient removal of phosphorous pollution (73\% for $\mathrm{P}_{\text {tot }}$ and $58 \%$

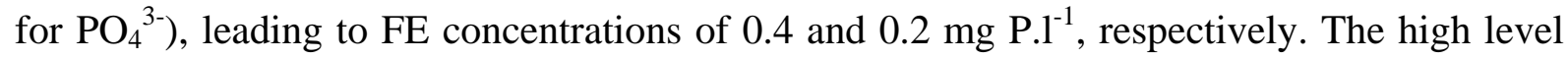
of phosphorous abatement is related to the assimilation of phosphorus by bacteria.

During the three campaigns conducted, the biofiltration units operated at nominal flow, and the removal rates of typical wastewater parameters were close to those obtained with conventional operating procedures ( $87 \% \pm 7 \%$ for TSS, $84 \% \pm 3 \%$ for CODt, $92 \% \pm 3 \%$ for BOD, $96 \% \pm 1 \%$ for TKN, and $99 \% \pm 1 \%$ for $\mathrm{NH}_{4}^{+}$). 


\section{Priority substances}

Table 3 lists the removal rates of priority substances using biofiltration. The removals for 23 substances remaining in decanted effluents are described. Detailed information on dissolved and sorbed chemicals in DE is available in the Supplementary Material section (Table 3). As previously stated, the pollutants can be classified as: i) poorly removed (< 20\%), ii) weakly removed (20-50\%), iii) moderately removed (50-80\%), and iv) efficiently removed $(>80 \%)$.

Depending on the compound, strong differences appeared regarding removal efficiency with biofiltration. On the whole, all pesticides (diuron, atrazine, isoproturon, metaldehyde and desethylatrazine) were poorly removed $(<20 \%)$, while all volatile compounds (1 HVOC, 4 BTEX and 3 LMW PAHs) were at least half removed. For other pollutants, removal rates varied from $20 \%$ to $80 \%$ (Table 3). Observed differences are due to differing processes occurring in the biofilter system. In theory, four mechanisms are involved herein: i) physical filtration, ii) volatilisation, iii) adsorption, and iv) biotransformation of substances. Although the exact apportioning of each mechanism cannot be assessed, it nevertheless remains possible for each chemical to be identified with a predominant mechanism.

i) Physical filtration. As previously mentioned, biofiltration units act as a physical filter, removing roughly $89 \% \pm 5 \%$ of TSS. This retention rate leads to a reduction in particulate pollutants. High removal rates are also observed for most of the hydrophobic compounds; this finding appears to be positively correlated with TSS removal. The highest particulate fraction removal rates were observed for NP (90\% $\pm 4 \%)$, followed by fluoranthene ( $85 \% \pm 2 \%)$, phenanthrene $(83 \% \pm 2 \%)$ and pyrene $(82 \% \pm 1 \%)$.

ii) Volatilisation. During both the $1^{\text {st }}$ and $2^{\text {nd }}$ biofilter system stages, the physical forces due to injecting diffused air induce atmospheric transfer (called air stripping). Given 
1 the use of air injection, volatile organic compounds can be volatilised. According to Rogers 2 (1996), compounds with a Henry's constant $\left(\mathrm{K}_{\mathrm{H}}\right)$ above $10^{-4} \mathrm{~atm} \cdot \mathrm{m}^{-3} \cdot \mathrm{mol}^{-1}$ and a $\mathrm{K}_{\mathrm{H}} / \log \mathrm{K}_{\mathrm{OW}}$

ratio exceeding $10^{-9}$ exhibit a high potential to volatilise. In this study, 8 compounds (toluene, xylenes, dichloromethane, chloroform, tri- and tetra-chloroethylene, naphthalene and phenanthrene) feature $\mathrm{K}_{\mathrm{H}}>10^{-4} \mathrm{~atm} \cdot \mathrm{m}^{-3} \cdot \mathrm{mol}^{-1}$. All these compounds are either moderately (50-80\%) or efficiently (> 80\%) removed. As regards BTEX and HVOCs, tetrachloroethylene has the highest removal rate $(82 \% \pm 4 \%)$, followed by trichloroethylene $(76 \% \pm 8 \%)$, toluene (71\% $\pm 4 \%)$ and dichloromethane (70\% $\pm 14 \%)$, while the lowest rate for volatile compounds was recorded for chloroform $(39 \% \pm 20 \%)$. The fact that tri- and tetra-chloroethylene are more widely removed can be correlated with their higher $K_{H}$ value $\left(1.81\right.$ and $1.04 \times 10^{-2}$ atm. $\mathrm{m}^{-3} \cdot \mathrm{mol}^{-1}$ ). For naphthalene and phenanthrene, the removal rates were also substantial, as shown by the major reduction in dissolved concentrations $(89 \% \pm 6 \%$ and $82 \% \pm 6 \%$, respectively).

iii) Adsorption on biomass. Adsorption can also occur within the biofilter system. The adsorption process corresponds to electrostatic interactions of positively-charged groups of chemicals with the negatively-charged surface of micro-organisms and, consequently, concerns ionic species. In this study, the adsorption process has been clearly highlighted for Zn and TBT, whose losses amount to about $30 \%$ and 20\%, respectively.

iv) Biotransformation of substances. Like for dissolved organic matter (with a removal rate of 79\%), chemicals can be degraded by biomass during biofiltration treatment. According to Byrns (2001), the complete mineralisation of xenobiotic compounds in treatment systems is rare, and the term biotransformation would more accurately describe potential changes to the composition and molecular structure of such a compound. Depending on their biodegradability, the three following pollutant types are distinguished: i) easily biodegradable, ii) moderately biodegradable, and iii) resistant to biodegradation or refractory. 
1 Given the short hydraulic retention time in the biofilter system (approx. 90 min for all three stages), it can reasonably be assumed that only the easily or moderately biodegradable compounds can be biodegraded.

For example, biodegradation process can explain the differences of removal between volatile compounds exhibiting a quite similar volatilization potential $\left(2.7 \times 10^{-4}<\mathrm{K}_{\mathrm{H}}<6.3 \mathrm{x}\right.$ $10^{-3}$ atm. $\mathrm{m}^{-3} \cdot \mathrm{mol}^{-1}$ ). Indeed, a more important removal is observed for readily biodegradable compounds such as naphthalene and phenanthrene in comparison to moderately degradable compounds (dichloromethane and chloroform). This observation is in accordance with study led by McNally et al. (1998), who demonstrated that LMW PAHs prove to be readily biodegradable under both aerobic and denitrifying conditions.

Similarly, biodegradation process can be responsible of a decrease of dissolved concentration for no volatile compounds $\left(\mathrm{K}_{\mathrm{H}}<10^{-4} \mathrm{~atm} \cdot \mathrm{m}^{-3} \cdot \mathrm{mol}^{-1}\right)$. For example, a reduction of dissolved concentrations was observed for DEHP (from 20 to $60 \%$ depending on the sampling campaign) and nonylphenols (10 - $60 \%)$ which are recognized as easily biodegradable compounds (Ying et al., 2002, Fauser et al., 2003). A slighter losses have even been observed for fluoranthene (0 - $30 \%$ ) and fluorene (55 - $83 \%)$.

The removal of chemicals in a biofiltration system is compound-dependent and dues to several mechanisms. The multiplicity and complexity of processes involved in chemical removal do not allow for a simple generalisation of results obtained. Though an accurate prediction of pollutant removal is not possible from their physico-chemical properties alone, two groups of chemicals with differing biofiltration-induced removal rates can still be clearly identified: i) hydrophobic or volatile compounds, for which moderate to high removal rates are observed; and ii) hydrophilic compounds, which are neither volatile nor easily biodegradable and hence expected to be poorly removed. High removal rates were indeed recorded for hydrophobic compounds (mainly in the particulate fraction) or easily volatilised 
1 compounds following air injection. Total removal ranged from $50 \%$ to over $80 \%$ for

2 compounds with $\mathrm{K}_{\mathrm{H}}>1 \times 10^{-4}$ atm. $\mathrm{m}^{-3} \cdot \mathrm{mol}^{-1}$ and between $50 \%$ and $80 \%$ for hydrophobic compounds (log $\mathrm{K}_{\mathrm{ow}}>4$ ) due to TSS filtration. On the other hand, poor removal was observed for pesticides. This low rate (< 20\%) with biofiltration is tied to the low hydrophobicity (log $\left.\mathrm{K}_{\mathrm{ow}}<2.6\right)$, combined with both the low volatilisation potential $(1.53 \mathrm{x}$ $10^{-9}<\mathrm{K}_{\mathrm{H}}<3.46 \times 10^{-5} \mathrm{~atm} \cdot \mathrm{m}^{-3} \cdot \mathrm{mol}^{-1}$ ) and low biodegradability of such compounds.

\subsubsection{Concentrations in final effluents}

To provide a complete overview of biofiltration performance, the quality of discharged effluents was also investigated. Out of the 39 pollutants initially detected in RS, 20 compounds including 10 substances listed in the WFD exhibited concentrations above the discharged effluent detection limit (Fig. 7). More detailed information on the dissolved and particulate concentrations is available in the Supplementary Material section (Table 4). These higher concentrations were found for Zn (40-50 $\left.\mu \mathrm{g} . \mathrm{l}^{-1}\right)$ and DEHP (2.1-5.8 $\left.\mu \mathrm{g} . \mathrm{l}^{-1}\right)$, followed by chloroform (1.2 $\left.\mu \mathrm{g} . \mathrm{l}^{-1}\right)$, tetrachloroethylene (0.4-1.2 $\left.\mu \mathrm{g} . \mathrm{l}^{-1}\right)$ and NP (0.1-0.3 $\left.\mu \mathrm{g} . \mathrm{l}^{-1}\right)$. High levels of DEHP and, to a lesser extent of NP can pose an environmental threat since these compounds are recognised as endocrine disrupters and have been found to persist as pollutants in the environment, in addition to being blamed for causing developmental disorders and/or fertility problems (Jobling et al., 2002; Ying et al., 2002). For the other compounds, concentrations lie within the ng. $\mathrm{l}^{-1}$ range and typically vary from 0.005 to 0.3 $\mu g . l^{-1}$. In final effluents, 8 pesticides were present with concentrations generally ranging between 0.03 and $1.23 \mu \mathrm{g} . \mathrm{l}^{-1}$. Given their poor removal during clarification and biofiltration treatments, the effluents revealed concentration ranges quite similar to those observed in raw sewage, except for AMPA. Of the three campaigns carried out, AMPA was detected twice with higher concentrations in final effluents than in RS or DE. This increase could reflect 
1 local AMPA production relative to the degradation of glyphosate, but more likely to the degradation of some detergent components (Koplin et al., 2006; Skark et al., 1998).

\section{Conclusion}

This study has investigated the occurrence of priority substances in raw sewage as well as the removal of a wide range of contaminants by means of both lamella separator and biofiltration techniques. 88 substances, ranked into 13 groups of compounds, were determined in raw sewage and at particular points in the WWTP.

This paper first confirmed that a broad array of contaminants is present in raw sewage. Of the 88 molecules investigated, 39 substances (18 of which appeared on the WFD list) were detected. On the whole, metal concentrations ranged from 15 to $260 \mu \mathrm{gg} \cdot \mathrm{l}^{-1}$, while other organic pollutants were found to lie in the $\mu \mathrm{g} . \mathrm{I}^{-1}$ range, with the exception of DEHP (13.5$\left.24.7 \mu \mathrm{g} . \mathrm{l}^{-1}\right)$ and volatile organic compounds $\left(0.8-4.8 \mu \mathrm{g} . \mathrm{l}^{-1}\right)$. The presence of most of these chemicals has resulted from their extensive use in a wide variety of consumer products and household appliances.

The performance of both techniques, as regards the removal of conventional pollutants and priority substances, was then assessed. The differing capability of each technique to remove pollutants was obvious; nonetheless, pollutant removal was still quantitatively dependent upon the physico-chemical properties of the chemicals and operating conditions within the facility.

By operating at low coagulant and flocculant doses (25-40 $\mathrm{g} \mathrm{FeCl}_{3} \cdot \mathrm{m}^{-3}$ and $0.30-0.45 \mathrm{~g}$ polymer. $\mathrm{m}^{-3}$ ), lamella clarification can effectively clarify wastewater, thus achieving total solid and organic load reductions of $86 \%$ and $65 \%$ respectively for COD. The adjustment of coagulant and polymer doses, according to RS quality entering the facility, enables maintaining this performance level. As for the chemicals, lamella clarifier can also effectively retain most of those tracked. Backed by the theoretical approach, the removal of organic 
1 chemicals is highly dependent on the $\log \mathrm{K}_{\mathrm{ow}}$ of the compound under consideration.

2 Compounds with a strong hydrophobic character are removed to a significant extent (similar

to TSS). This removal mechanism operates through TSS sedimentation and through sorption to sludge particles with subsequent transfer to sludge processing systems. Conversely, hydrophilic compounds (18 compounds with $\log \mathrm{K}_{\mathrm{ow}}<4$ out of the 39 detected in raw sewage) were poorly removed $(<20 \%)$.

By combining physical and biological purification processes, biofiltration can effectively treat both carbonaceous and nitrogenous pollution. Concerning the removals of priority pollutants, this study has also demonstrated that chemical removal in biofiltration system is compound-dependent and derived from several mechanisms, including: i) physical filtration of suspended solids, ii) volatilisation or air stripping, iii) adsorption on biomass, and iv) biotransformation of substances. Of the 23 substances detected in decanted effluents, 12 were removed at over $50 \%$ and 3 over $80 \%$, while 5 pesticides were poorly removed $(<20 \%)$. While the combination of complex processes within biofilter systems does not allow an accurate prediction of pollutant evolution, two groups of chemicals are nonetheless clearly distinguished for their removal rates with biofiltration: i) hydrophobic or volatile compounds, for which moderate to high rates are observed; and ii) hydrophilic compounds, which are neither volatile nor easily biodegradable and hence expected to be poorly removed.

By examining the occurrence and removal of a broad set of pollutants by lamella clarification and biofiltration, this study has provided relevant information on both wastewater treatment technologies and their ability to remove contaminants. Considering that both techniques are currently implemented in WWTPs, the data generated for a predetermined number of hazardous substances may be used in the future to identify other techniques of potential significance and/or deserving of implementation within the Water Framework 
1 Directive. Such additional knowledge is even more necessary given that the two techniques

are also recommended and have become increasingly popular for stormwater management.

\section{References}

Blanchoud, H., Moreau-Guigon, E., Farrugia, F., Chevreuil, M., Mouchel, J.M. (2007). Contribution by urban and agricultural pesticide uses to water contamination at the scale of the Marne watershed. Science of the Total Environment 375, 168-179.

Byrns, G. (2001). The fate of xenobiotic organic compounds in wastewater treatment plants. Water Research 35, 2523-2533.

CEPA (1993). Priority Substances List assessment report - Tetrachloroethylene. $<$ http://www.hc-sc.gc.ca/ewh-semt/alt_formats/hecs-sesc/pdf/pubs/contaminants/psl1lsp1/tetrachloroethylene/tetrachloroethylene-eng.pdf> .

Chang, D., Seo, S.C., Hong, K.H. (2004). Pre-denitrification and post-nitrification in an integrated anaerobic/aerobic filter system for advanced treatment of municipal wastewater. Journal of Industrial and Engineering Chemistry 10, 354-360.

Clara, M., Strenn, B., Gans, O., Martinez, E., Kreuzinger, N., Kroiss, H. (2005). Removal of selected pharmaceuticals, fragrances and endocrine disrupting compounds in a membrane bioreactor and conventional wastewater treatment plants. Water Research 39, 4797-4807.

Fauser, P., Vikelsøe, J., Sørensen, P.B., Carlsen, L. (2003). Phthalates, nonylphenols and LAS in an alternately operated wastewater treatment plant--fate modelling based on measured concentrations in wastewater and sludge. Water Research 37, 1288-1295.

Gasperi, J., Rocher, V., Moilleron, R., Chebbo, G. (2007). Review on the hydrocarbon fate within combined sewers: Case of the "Le Marais" urban catchment (1994-2005). Polycyclic Aromatic Compounds 27, 123-141. 
Gasperi, J., Garnaud, S., Rocher, V., Moilleron, R. (2008a). Priority pollutants in wastewater and combined sewer overflow. Science of the Total Environment 407, 263-272.

Gasperi, J., Kafi-Benyahia, M., Lorgeoux, C., Moilleron, R., Gromaire, M.C., Chebbo, G. (2008b). Wastewater quality and pollutant loads in combined sewers during dry weather periods. Urban Water Journal 5, 305-314.

Imasuen, E., Judd, S., Sauvignet, P. (2004). High-rate clarification of municipal wastewaters: a brief appraisal. Journal of Chemical Technology and Biotechnology 79, 914917.

Jacobsen, B.N., Kjersgaard, D., Winther-Nielsen, M., Gustavson, K. (2004). Combined chemical analyses and biomonitoring at Avedoere wastewater treatment plant in 2002. Water Science and Technology 50, 37-43.

Jobling, S., Beresford, N., Nolan, M., Rodgers-Gray, T., Brighty, G.C., Sumpter, J.P., Tyler, C.R. (2002). Altered sexual maturation and gamete production in wild roach (Rutilus rutilus) living in rivers that receive treated sewage effluents. Biology of Reproduction 66, 272-281.

Karickhoff, S.W. (1984). Organic pollutant sorption in aquatic systems. Journal of Hydrologic Engineering 110.

Katsoyiannis, A., Samara, C. (2004). Persistent organic pollutants (POPS) in the sewage treatment plant of Thessaloniki, northern Greece: occurrence and removal. Water Research 38, 2685-2698.

Kolpin, D.W., Thurman, E.M., Lee, E.A., Meyer, M.T., Furlong, E.T., Glassmeyer, S.T. (2006). Urban contributions of glyphosate and its degradate AMPA to streams in the United States. Science of The Total Environment 354, 191-197.

Le Tallec, X., Vidal, A., Thornberg, D. (1999). Upflow biological filter: modeling and simulation of filtration. Water Science and Technology 39, 79-84. 
McNally, D.L., Mihelcic, J.R., Lueking, D.R. (1998). Biodegradation of three- and

four-ring polycyclic aromatic hydrocarbons under aerobic and denitrifying conditions. Environmental Science \& Technology 32, 2633-2639.

Mendoza-Espinosa, L., Stephenson, T. (1999). A review of biological aerated filters (BAFs) for wastewater treatment. Environmental Engineering Science 16, 201-216.

Payraudeau, M., Paffoni, C., Gousailles, M. (2000). Tertiary nitrification in an up-flow biofilter on floating media: influence of temperature and COD load. Water Science and Technology 41, 21-27.

Rocher, V., Paffoni, C., Gonçalves, A., Legaigneur, V., Dutot, A., Gousailles, M. (2006). Le traitement des eaux usées par biofiltration : cas de la station Seine Centre (SIAAP). Techniques Sciences et Méthodes 10, 105-125.

Rocher, V., Paffoni, C., Gonçalves, A., Azimi, S., Gousailles, M. (2008). Municipal wastewater treatment by biofiltration: SIAAP feedback. Revue des Sciences de l'Eau 21, 475485.

Rogers, H.R. (1996). Sources, behaviour and fate of organic contaminants during sewage treatment and in sewage sludges. Science of The Total Environment Organic Contaminants in Sewage Sludges 185, 3-26.

Rueppel, M.L., Brightwell, B.B., Schaefer, J., Marvel, J.T. (2002). Metabolism and degradation of glyphosate in soil and water. Journal of Agricultural and Food Chemistry 25, 517-528.

Rule, K.L., Comber, S.D.W., Ross, D., Thornton, A., Makropoulos, C.K., Rautiu, R. (2006a). Sources of priority substances entering an urban wastewater catchment--trace organic chemicals. Chemosphere 63, 581-591. 
Rule, K.L., Comber, S.D.W., Ross, D., Thornton, A., Markropoulos, C.K., Rautiu, R. (2006b). Survey of priority substances entering thirty English wastewater treatment works. Water and Environment Journal 20, 177-184.

Skark, C., Zullei-Seibert, N., Schottler, U., Schlett, C. (1998). The occurrence of glyphosate in surface water. International Journal of Environmental Analytical Chemistry 70, 93-104.

Tchobanoglous, G., Burton, F., Stensel, H. (2003). Wastewater Engineering. Treatment and Reuse. 4th ed. Metcalf and Eddy, McGraw-Hill, New York, 1819 p.

Ternes, T.A., Herrmann, N., Bonerz, M., Knacker, T., Siegrist, H., Joss, A. (2004). A rapid method to measure the solid-water distribution coefficient (K-d) for pharmaceuticals and musk fragrances in sewage sludge. Water Research 38, 4075-4084.

Thomaidis, N.S., Stasinakis, A.S., Gatidou, G., Morabito, R., Massanisso, P., Lekkas, T.D. (2007). Occurrence of organotin compounds in the aquatic environment of Greece. Water Air and Soil Pollution 181, 201-210.

Vogelsang, C., Grung, M., Jantsch, T.G., Tollefsen, K.E., Liltved, H. (2006). Occurrence and removal of selected organic micropollutants at mechanical, chemical and advanced wastewater treatment plants in Norway. Water Research 40, 3559-3570.

Wams, T.J. (1987). Diethylhexylphthalate as an environmental contaminant - a review. Science of the Total Environment 66, 1-16.

Ying, G.-G., Williams, B., Kookana, R. (2002). Environmental fate of alkylphenols and alkylphenol ethoxylates--a review. Environment International 28, 215-226.

Zgheib, S., Moilleron, R., Chebbo, G. (2008). Screening of priority pollutants in urban stormwater: innovative methodology. Water Pollution IX 111, 235-244. 


\section{Figure caption}

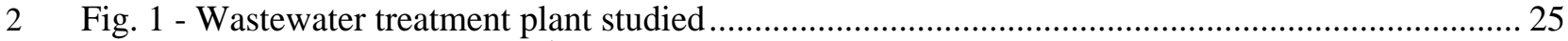

$3 \quad$ Fig. 2 - RS concentrations $\left(\mu \mathrm{g} . \mathrm{l}^{-1}\right)$ and limits of detection .............................................................. 26

$4 \quad$ Fig. 3 - Removal of carbonaceous, nitrogenous and phosphorous pollutions by lamella separator...... 27

$5 \quad$ Fig. 4 - Removals of pollutants with lamellar clarifier, according to $\log \mathrm{K}_{\mathrm{OW}}$.................................... 28

$6 \quad$ Fig. 5 - Comparison between experimental and theoretical removals by lamellar clarifier .................. 29

$7 \quad$ Fig. 6 - Removal of carbonaceous, nitrogenous and phosphorous pollutions by biofiltration............... 30

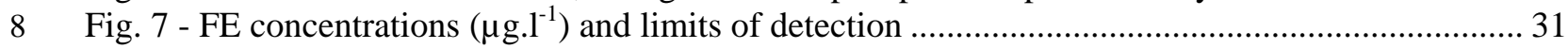




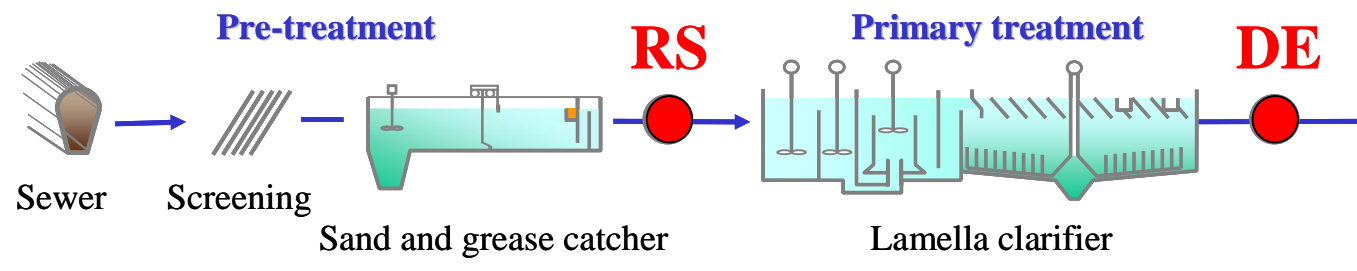

Biological treatment

\section{Seine River}

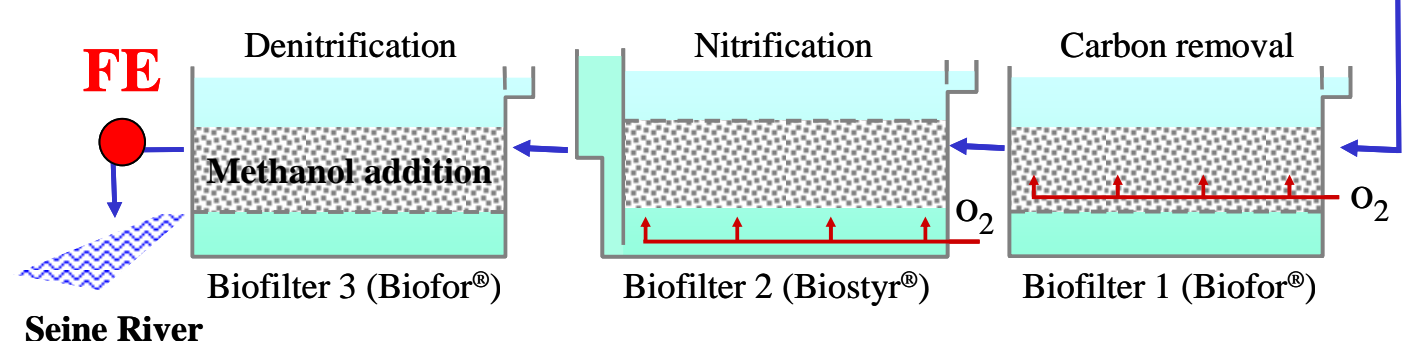

Fig. 1 - Wastewater treatment plant studied

4 


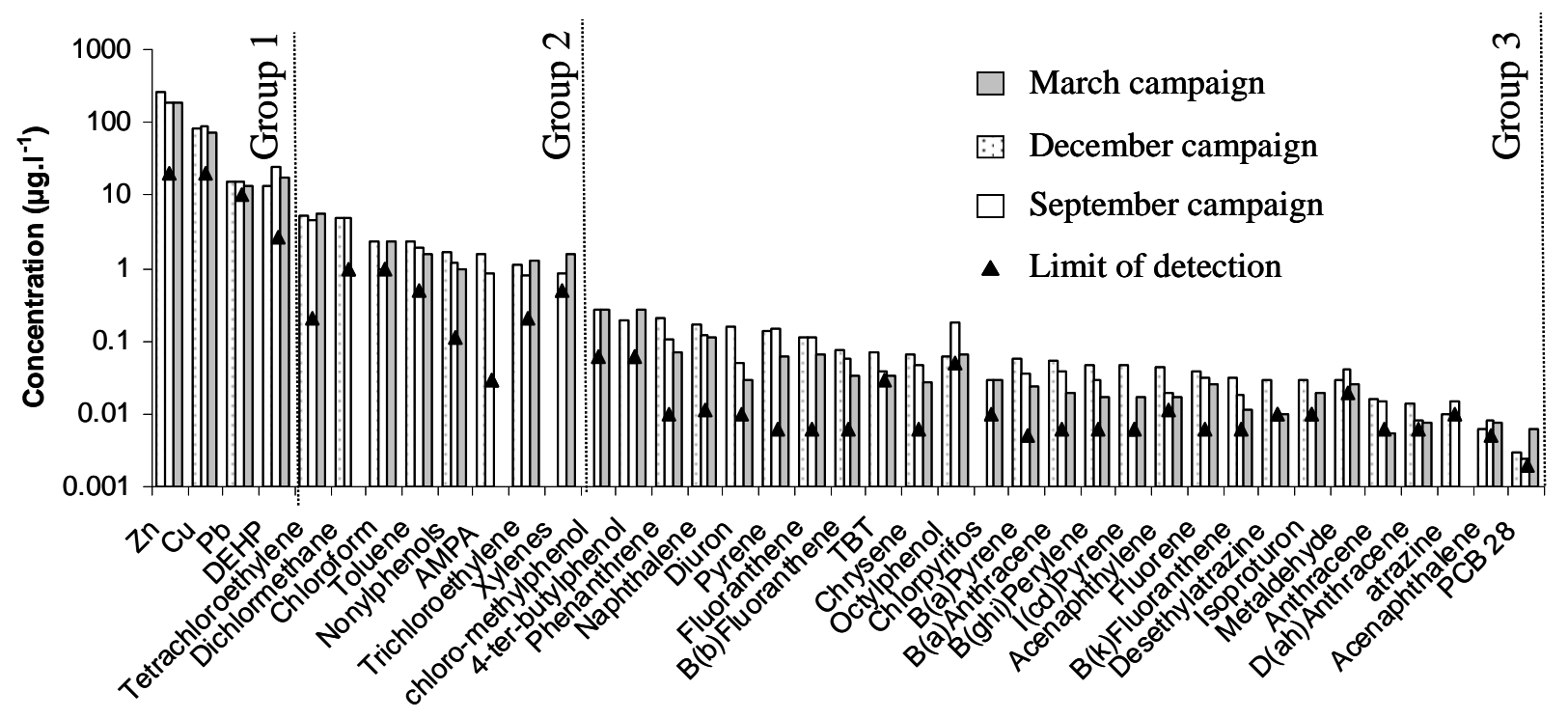

Fig. 2 - RS concentrations ( $\mu$ g. ${ }^{-1}$ ) and limits of detection 


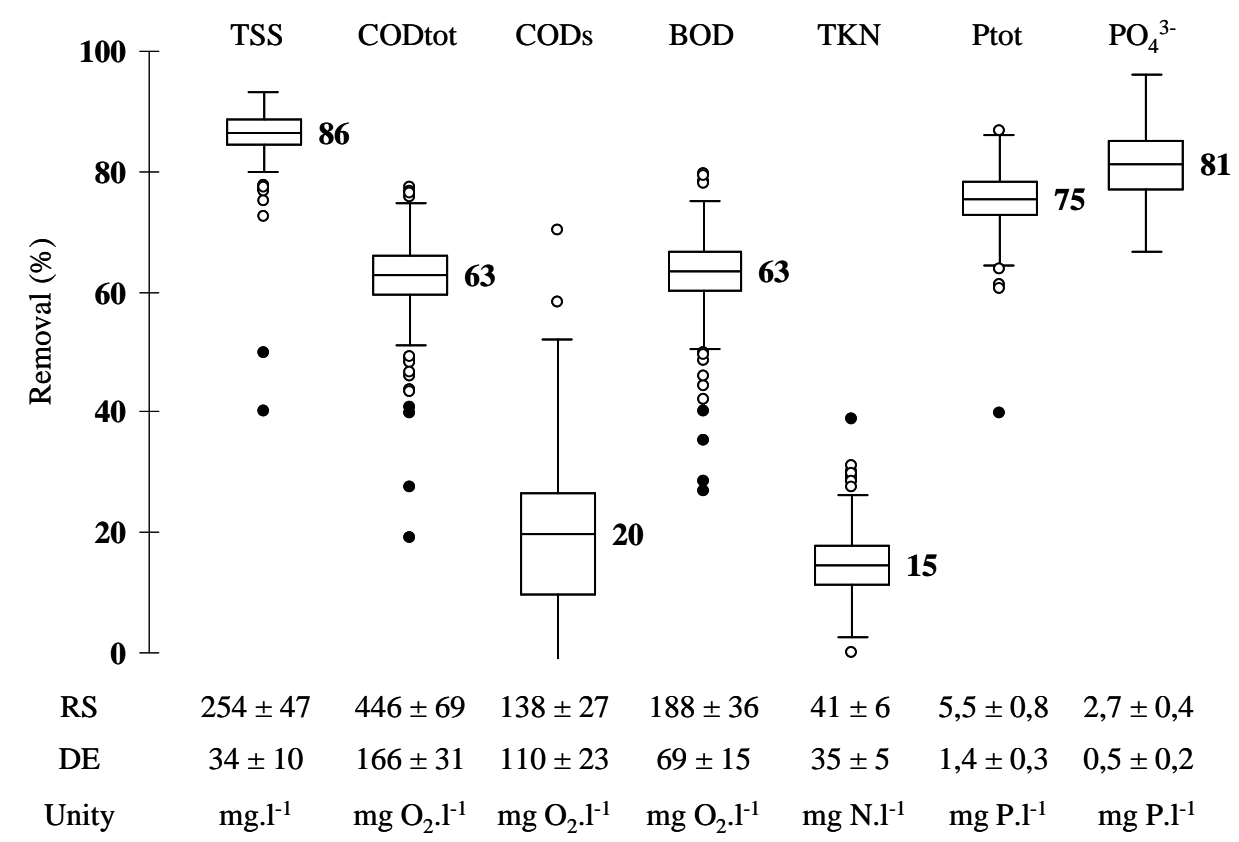

Fig. 3 - Removal of carbonaceous, nitrogenous and phosphorous pollutions by lamella separator 


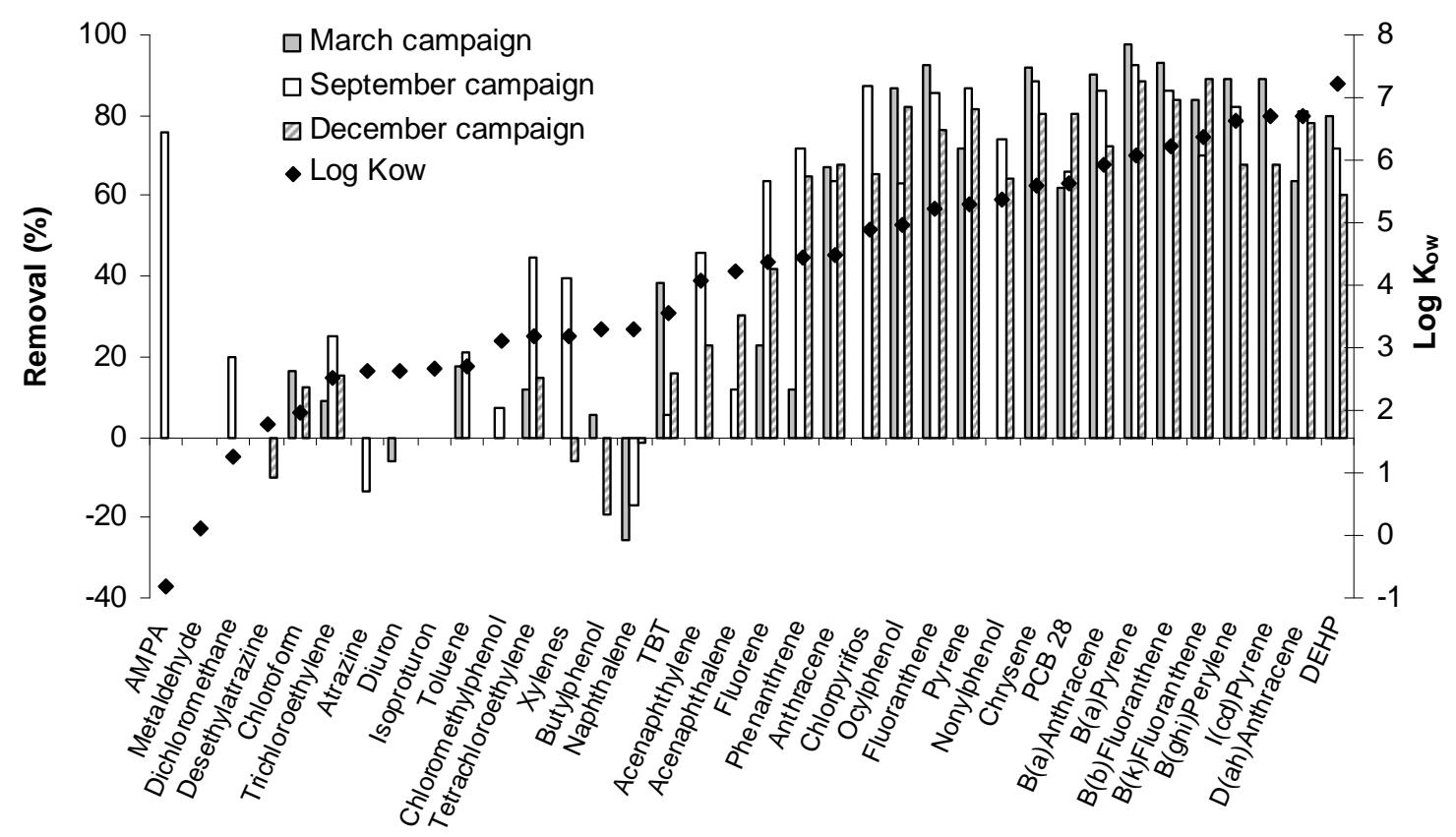

Most $K_{\text {ow }}$ values were originally extracted from the ScorePP database (Source Control Options for Reducing Emissions of Priority Pollutants, http://www.scorepp.eu).

Fig. 4 - Removals of pollutants with lamellar clarifier, according to log $\mathrm{K}_{\mathrm{OW}}$ 5 


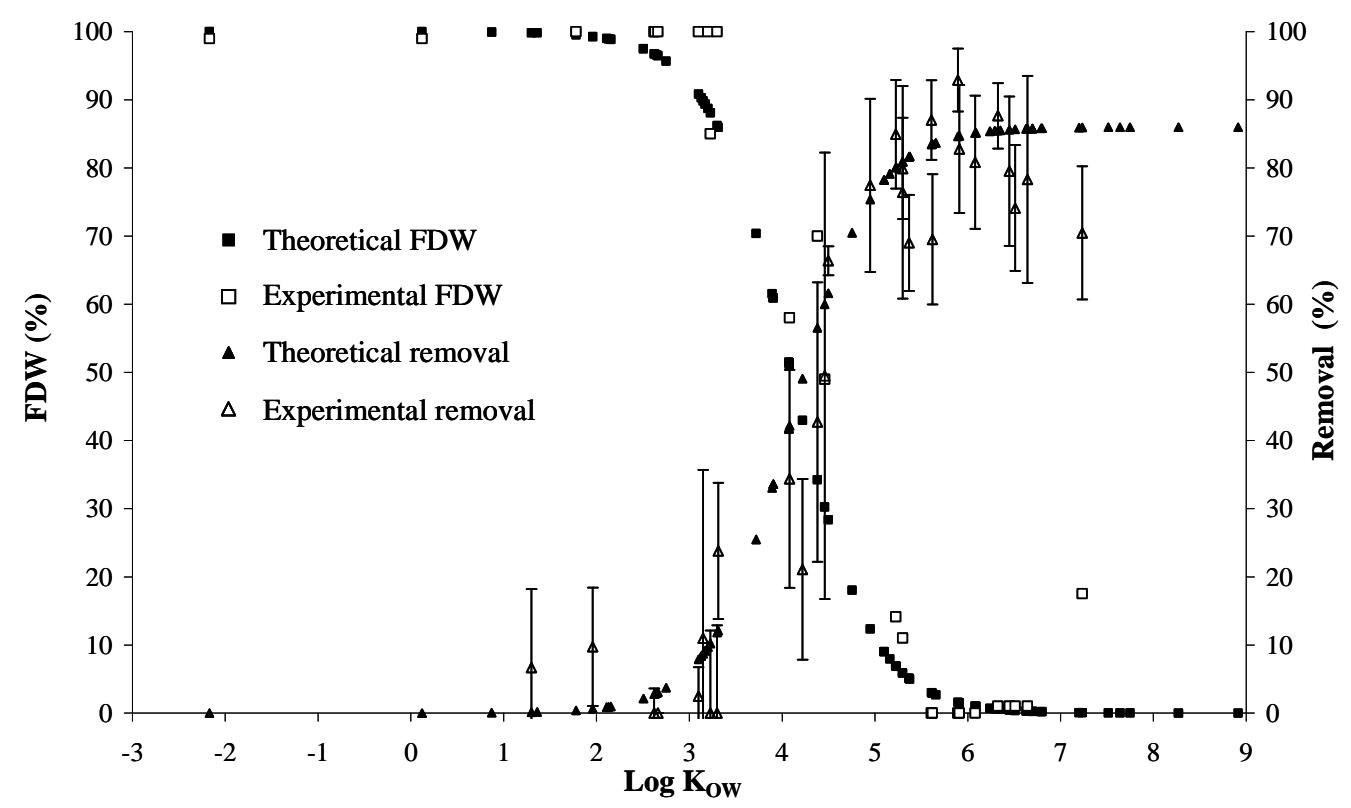

Fig. 5 - Comparison between experimental and theoretical removals by lamellar clarifier 4 


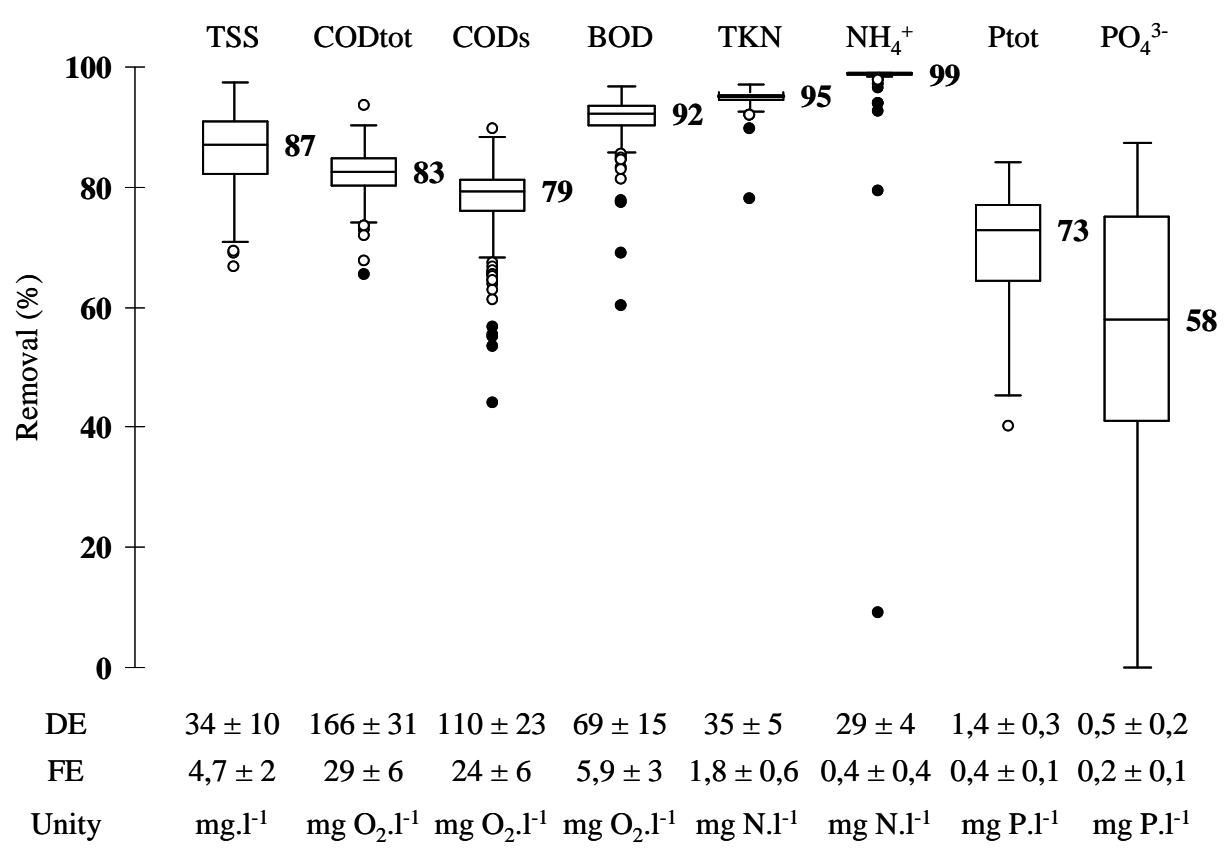

Fig. 6 - Removal of carbonaceous, nitrogenous and phosphorous pollutions by biofiltration 3 


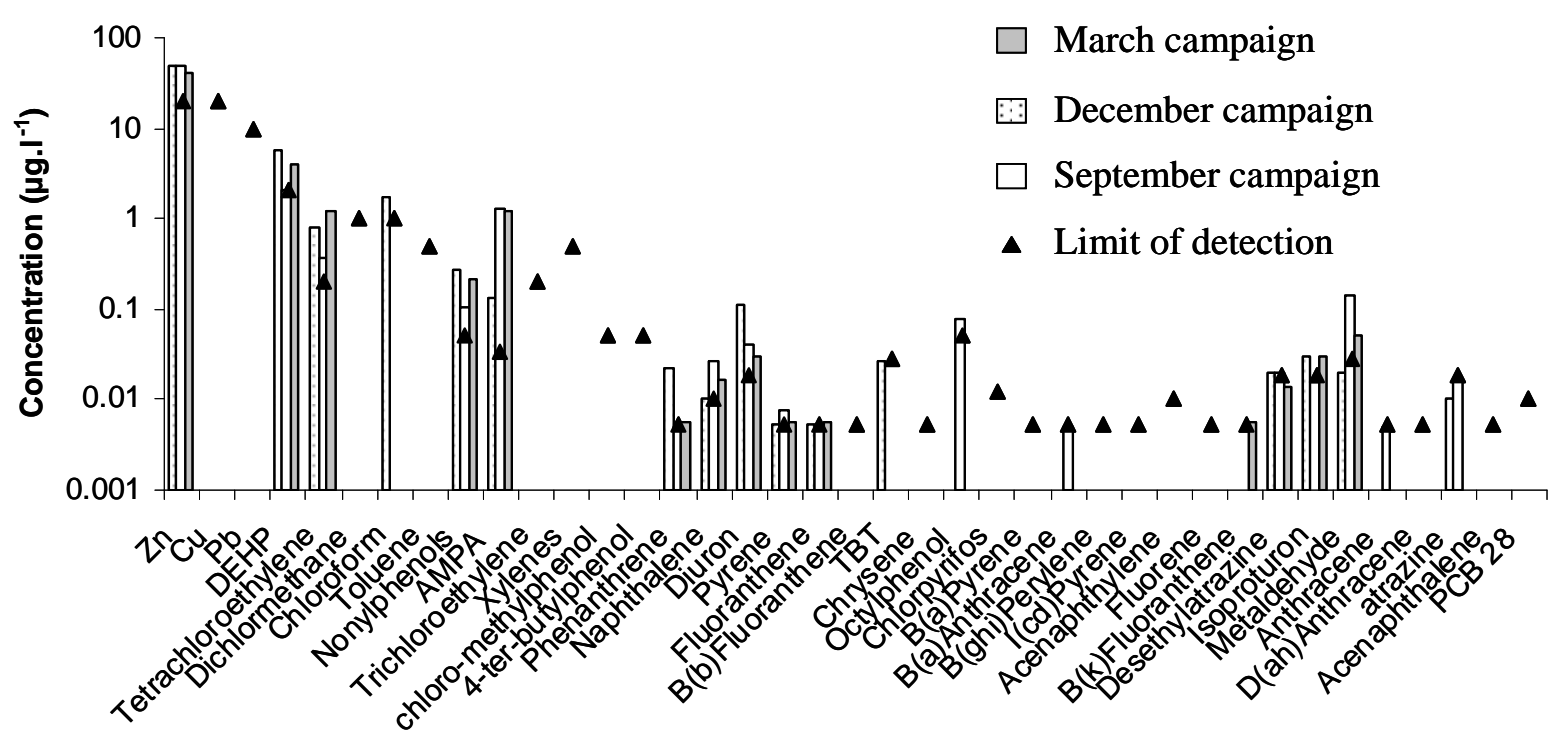

Fig. 7 - FE concentrations ( $\mu$ g. ${ }^{-1}$ ) and limits of detection 


\section{Table caption}

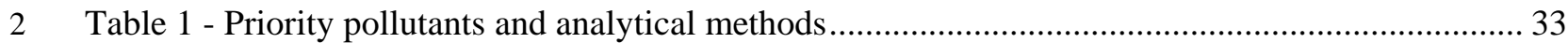

$3 \quad$ Table 2 - Removals of pollutants by lamellar clarifier ........................................................................ 34

$4 \quad$ Table 3 - Removals of pollutants by biofiltration ................................................................................ 35

6 
Table 1 - Priority pollutants and analytical methods

\begin{tabular}{llllc}
\hline Groups $^{1}$ & Total $^{2}$ & Standards & Methods & Phase $^{4}$ \\
\hline Alkylphenols & $5(2)$ & ISO 18857-1 & GC-MSMS & P + D \\
BTEX & $5(1)$ & NF EN ISO 11423-1 & GC-MS & T \\
Chloroalkanes & $1(1)$ & Internal method & CG-ECD & P + D \\
Chlorobenzenes & $5(3)$ & EN ISO 6468 & GC-MS & P + D \\
Chlorophenols & $1(1)$ & NF EN 12673 et ISO 6468 & GC-MSMS & P + D \\
HVOCs & $7(4)$ & NF EN ISO 10301 + 6468 & GC-MS & T \\
PAHs & $16(8)$ & ISO 17993 & HPLC-Fluo & P + D \\
Metals & $8(4)$ & NF EN ISO 11885 + 1483 & ICP and AAS & T + D \\
Organotins & $3(3)$ & NF EN ISO 17353 & GC-MS & P + D \\
PBDEs & $3(1)$ & ISO 22032 & CG-ECD & P + D \\
PCBs & 8 & NF EN ISO 6468 & GC-MS-MS & P + D \\
Pesticides & $25(12)$ & NF EN ISO 11369+ Internal & GC-MS & method \\
Phthalates & $1(1)$ & Internal method & UPLC-MSMS & D \\
\hline
\end{tabular}

(1) Compound groups: BTEX = benzene, toluene, ethylbenzene and xylenes, HVOC = halogenated volatile organic compounds, $P A H s=$ polycyclic aromatic hydrocarbons, $P B D E=$ polybromodiphenylethers, $P C B=$ polychlorobiphenyls.

(2) The substance in brackets is listed in the WFD.

(3) Analytical methods: ICP = inductively coupled plasma, AAS = atomic absorption spectrometry, GC = gas chromatography, GC-ECD = GC with electron capture detector, GC-MS = GC with mass spectrometer, GC-MSMS = GC gas chromatography with tandem mass spectrometer, HPLC-fluo $=$ High pressure liquid chromatography with fluorescent detector, UPLC-MSMS = ultra performance liquid chromatography with tandem mass spectrometer.

(4) Phase considered with $D=$ dissolved, $P$ = particulate, $T=$ Total 
1 2

\begin{tabular}{|c|c|c|c|c|}
\hline $\mathbf{n}$ & $<20 \%$ & $20-50 \%$ & $50-80 \%$ & $>80 \%$ \\
\hline $\begin{array}{c}m \\
\| \\
\end{array}$ & $\begin{array}{c}\text { tributyl tin } \\
\text { toluene } \\
\text { chloroform } \\
\text { trichloroethylene } \\
\text { tetrachloroethylene } \\
\text { diuron } \\
\text { metaldehyde } \\
\text { naphthalene } \\
\text { acenaphthylene } \\
\text { acenaphthene }\end{array}$ & $\begin{array}{c}\mathrm{Pb}^{*} \\
\text { fluorene } \\
\text { phenanthren } \\
\text { e }\end{array}$ & $\begin{array}{c}\mathrm{Cu} \\
\text { Zn } \\
\text { chlorpyrifos } \\
\text { DEHP } \\
\text { nonylphenols } \\
\text { para-tert-octylphenol } \\
\text { anthracene } \\
\text { dibenz(ah)anthracen } \\
\text { e } \\
\text { pyrene } \\
\text { PCB 28 }\end{array}$ & $\begin{array}{c}\text { benzo(a)pyrene } \\
\text { benzo(b)fluoranthen } \\
\text { e } \\
\text { benzo(k)fluoranthen } \\
\text { e } \\
\text { benzo(ghi)perylene } \\
\text { fluoranthene } \\
\text { benzo(a)anthracene } \\
\text { chrysene }\end{array}$ \\
\hline $\begin{array}{c}\text { N } \\
\| \\
\text { II }\end{array}$ & $\begin{array}{c}\text { xylenes } \\
\text { dichloromethane } \\
\text { atrazine } \\
\text { desethylatrazine } \\
\text { isoproturon } \\
\text { AMPA } \\
\text { chloromethylphenol } \\
\text { butylphenol }\end{array}$ & - & - & indeno(cd)pyrene \\
\hline Total & 18 & 3 & 10 & 8 \\
\hline
\end{tabular}


1

Table 3 - Removals of pollutants by biofiltration

\begin{tabular}{|c|c|c|c|c|}
\hline n & $<20 \%$ & $20-50 \%$ & $50-80 \%$ & $>80 \%$ \\
\hline $\begin{array}{l}m \\
\| \\
=\end{array}$ & diuron & $\begin{array}{l}\text { tributyl tin } \\
\text { DEHP }\end{array}$ & $\begin{array}{c}\text { toluene } \\
\text { trichloroethylene } \\
\text { nonylphenols } \\
\text { fluoranthene } \\
\text { fluorene } \\
\text { pyrene }\end{array}$ & $\begin{array}{c}\text { tetrachloroethylen } \\
\text { e } \\
\text { naphthalene } \\
\text { phenanthrene }\end{array}$ \\
\hline $\begin{array}{l}N \\
I 1 \\
=\end{array}$ & $\begin{array}{c}\text { atrazine } \\
\text { isoproturon } \\
\text { metaldehyde } \\
\text { desethylatrazin } \\
\text { e }\end{array}$ & Zn & $\begin{array}{c}\text { chloroform } \\
\text { dichloromethane } \\
\text { chloromethylpheno } \\
\text { l } \\
\text { 4-ter-butyl phenol } \\
\text { benzo(a)pyrene } \\
\text { xylenes }\end{array}$ & - \\
\hline Total & 5 & 3 & 12 & 3 \\
\hline
\end{tabular}

2 